\title{
Effect of Body Position on Post-Lumbar Puncture Headache and Urinary Retention After Spinal Anaesthesia in Orthopaedic Cases: Concerns in Post-Operative Ambulation and Rehabilitation
}

\author{
Nirab Kayastha', Amit Joshi', Bhuwan Kunwar ${ }^{2}$ and Santosh Khadka ${ }^{2}$ \\ 1Department of Orthopaedics, Nepalese Army Institute of Health Sciences, Shree Birendra Hospital, \\ Chhauni, Kathmandu, Nepal \\ 2Department of Anaesthesiology, Nepalese Army Institute of Health Sciences, Shree Birendra Hospital, \\ Chhauni, Kathmandu, Nepal
}

\begin{abstract}
Introduction: Postural headache occurs in up to $70 \%$ of the patients who receive spinal anaesthesia. They further experience difficulty in bladder voiding. Both of these complications deter the orthopaedic patients who undergo procedures in the lower limb from having early mobilisation. It is widely suggested that a period of bed rest is necessary to avert spinal headache whereas early mobilisation aggravates the condition. The aim of our study was to compare the effect of body position on post-lumbar puncture headache and urinary retention after spinal anaesthesia in orthopaedic patients.

Methods: We did a prospective randomised single-center study in a leading teaching institute of our country. There were 200 patients. Initially they were randomly divided into two groups- study and control- to see if there was any correlation between body position and PLPH. Since the body posture postoperatively was not found to be initiating factor for PLPH, whole of the 200 patients were analysed together for other criteria.

Results: We had 37 patients (18.5\%) who had PLPH among the 200 patients. The number of patients developing the condition in study and control groups were 17 and 20 respectively. A total of twenty-three patients $(11.5 \%)$ needed catheterisation in post-operative ward, the age group mostly needing Foley's catheter was 41-60 yrs. More patients in control group (16 out of 100) given bed rest to prevent PLPH needed urinary catheterisation.

Conclusions: Body position after spinal anaesthesia does not contribute to onset of PLPH. Moreover, the incidence of urinary catheterisation was more in patients given bed rest, which delayed mobilisation. We conclude that the patients need not be given strict bed rest in supine position after the lower limb procedures to facilitate early bladder voiding and mobilisation.

Key words: post lumber puncture headache; spinal anaesthesia; urinary retention
\end{abstract}

Correspondence: Nirab Kayastha, Department of Orthopaedics, Nepalese Army Institute of Health Sciences, Shree Birendra Hospital, Chhauni, Kathmandu, Nepal. Email: nirabk@hotmail.com

DOI: http://dx.doi.org/10.3126/mjsbh.v17i2.20191

Submitted on: 2018-06-07

Accepted on: 2018-06-26

This work is licensed under creative common license:

http://creativecommons.org/licenses/by-nc-nd/4.0/ (C) MJSBH 2018 


\section{INTRODUCTION}

Headache after lumbar puncture is common in patients who undergo operative procedures in lower limbs. It is reported in between $1 \%$ to $70 \%$ of patients. 1,2 Post-lumbar puncture headache (PLPH), as defined by International Headache society, is any headache after a lumbar puncture that worsens within 15 minutes of sitting or standing and is relieved within 15 minutes of lying down. ${ }^{3}$ The onset of headache contributes to the fear in patients while starting ambulation and rehabilitation as it might persists for several weeks in some cases.

The exact aetiology of PLPH is not clear and there are still controversies. The factors implicated are needle size influencing the leakage of CSF through the theca and the patients' personality and expectation of the procedure. ${ }^{1}$

There are many studies which have focused on treatment once the symptoms are present. The prevention of PLPH is equally important if we aim for early mobilisation of the orthopaedic patients post surgical procedures in lower limbs. Bed-rest in supine position is one of the methods described to prevent PLPH or recover from it. It was Sicard in

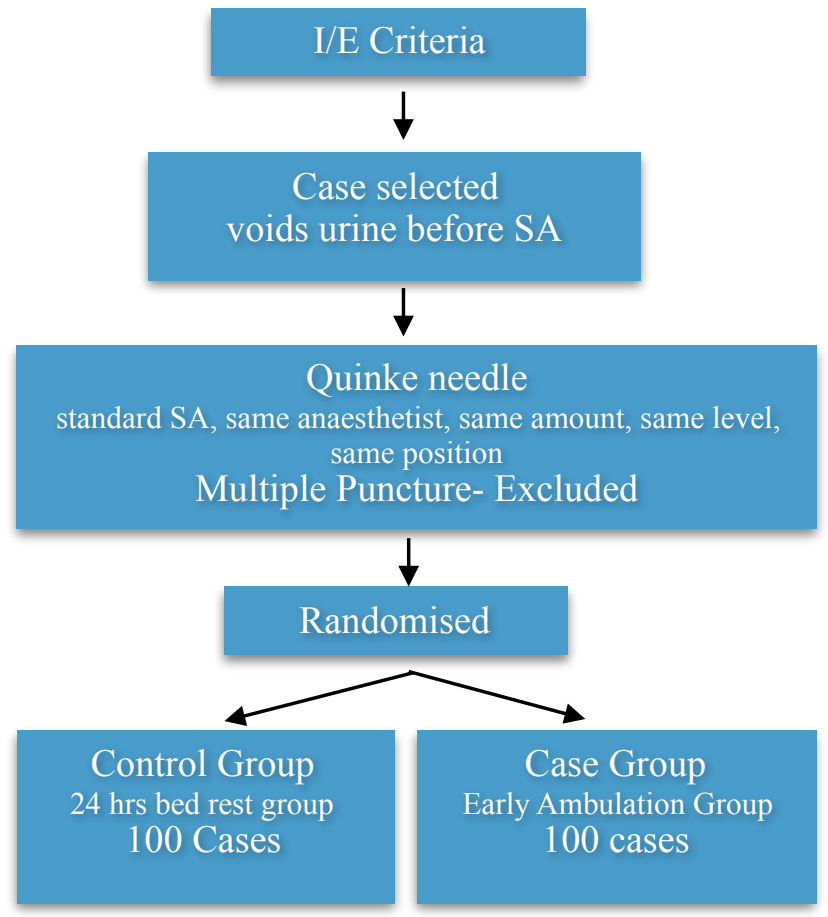

1902, who first recommended bed rest after a lumber puncture. He recommended rest for 24 hours after the procedure. Symptoms can be relieved by rest, but it is debatable whether bed rest prevents the development of symptoms. ${ }^{4,5}$

Besides spinal headache, urinary retention is one of the complications of spinal anaesthesia, the incidence of which is reported to be up to $69 \%{ }^{6}$ Post-operative urinary retention (POUR) is said to be present when the patient has palpable urinary bladder, pain in the lower abdomen and supra-pubic region, and they feel urgency, but are unable to void.

Since ability to void is one of the criteria for discharge followed by rehabilitation in patients undergoing orthopaedic procedures, POUR is an important aspect in peri-operative care. ${ }^{7}$ Male population seems to be more at risk of POUR. ${ }^{8}$ Intra-bladder pressure is increased with head-up positioning, which in turn is associated with ease of voiding. ${ }^{9}$ With these facts in perspective, we conducted this study to analyse whether bed rest was necessary to prevent PLPH in patients undergoing orthopaedic lower limb procedures under spinal anaesthesia.

\section{METHODS}

There were 200 patients studied from 2014 March to 2015 February for a period of one year. The patients included were aged 18 or more, undergoing various lower limb orthopaedic surgical procedures. Standard spinal anaesthesia was given with $3 \mathrm{ml}$ of $0.5 \%$ Bupivacaine - Heavy, the level was L3-L4, in sitting position. The needle used was 25G Quinke needle.

We divided exclusion criteria as preoperative, peroperative and post-operative. Pre-operative exclusion criteria were: a) migraine headache, b) chronic back or neck pain, c) previous history of post-dural puncture headache (PDPH), d) BPH of 


\begin{tabular}{|c|c|c|c|}
\hline Parameters & $\begin{array}{r}\text { Control } \\
\text { group }\end{array}$ & $\begin{array}{l}\text { Study } \\
\text { group }\end{array}$ & p \\
\hline $\begin{array}{l}\text { Age group (Yrs) } \\
\quad<20 \\
\quad 21-40 \\
41-60 \\
>60\end{array}$ & $\begin{array}{l}10 \\
47 \\
28 \\
15\end{array}$ & $\begin{array}{l}07 \\
62 \\
19 \\
12\end{array}$ & 0.19 \\
\hline $\begin{array}{l}\text { Sex } \\
\text { Male } \\
\text { Female }\end{array}$ & $\begin{array}{l}71 \\
29\end{array}$ & $\begin{array}{l}68 \\
32\end{array}$ & 0.6 \\
\hline $\begin{array}{l}\text { Co-morbidities } \\
\text { Yes } \\
\text { No }\end{array}$ & $\begin{array}{l}10 \\
90\end{array}$ & $\begin{array}{l}10 \\
90\end{array}$ & 0.97 \\
\hline $\begin{array}{l}\text { Previous history of } \\
\text { headache } \\
\text { Yes } \\
\text { No }\end{array}$ & $\begin{array}{r}8 \\
92\end{array}$ & $\begin{array}{r}6 \\
94\end{array}$ & 0.57 \\
\hline $\begin{array}{l}\text { Type of operation } \\
\text { Knee and below } \\
\text { Above knee }\end{array}$ & $\begin{array}{l}71 \\
29\end{array}$ & $\begin{array}{l}70 \\
30\end{array}$ & 0.87 \\
\hline
\end{tabular}

more than grade 2, e) obstructive uropathy and f) if previously catheterised.

Per-operative exclusion criteria were: a) multiple puncture, b) supplementary anaesthetic agent, c) bladder catheterisation intra-operatively. Postoperative exclusion criteria were: a) non-compliant patient, b) patient requiring more IV fluid than $2000 \mathrm{ml}, 3)$ patients requiring blood transfusion. The patients who met inclusion criteria were asked to void urine before the procedure and they were randomly assigned to control or the study group. There were 100 patients in each group.

Table 2. Onset of headache in two study groups

\begin{tabular}{|l|r|r|r|}
\hline $\begin{array}{l}\text { Onset of spinal } \\
\text { headache }\end{array}$ & \multicolumn{1}{l}{$\begin{array}{l}\text { Control } \\
\text { group }\end{array}$} & $\begin{array}{l}\text { Study } \\
\text { group }\end{array}$ & p \\
\hline Yes & 20 & 17 & 0.4 \\
\hline No & 80 & 83 & \\
\hline
\end{tabular}

\begin{tabular}{|l|r|r|r|}
\hline \multicolumn{3}{|c|}{ Table 3. Need of catheterisation } \\
\hline $\begin{array}{c}\text { Need for } \\
\text { catheterisation }\end{array}$ & $\begin{array}{c}\text { Control } \\
\text { group }\end{array}$ & $\begin{array}{c}\text { Study } \\
\text { group }\end{array}$ & p \\
\hline Yes & 16 & 7 & 0.04 \\
\hline No & 84 & 93 & \\
\hline
\end{tabular}

Post-operatively, the control group patients were asked for 24 hours bed rest, no pillow was allowed during that time, patients were asked to void bladder in lying down position into a urinal; if unable to do so, they were assessed for postoperative urine retention (POUR). After 24 hours they were allowed to sit and ambulate. In the study group patients were allowed early ambulation soon after arrival in post-op ward, were allowed to sit up once they recovered from spinal anaesthesia, they were accompanied to the toilet to void urine. If the patients were unable to pass urine, they were assessed for POUR and catheterisation was done.

The patients were allotted to two groups as shown in the flowchart above. Quinke needle was used, the anaesthetic, amount of medication, level of puncture and patient position was same in all 200 cases. Statistical analysis was done by using statistical package for social sciences (SPSS) version 11.5.

\section{RESULTS}

The two groups were not significantly different in terms of age, sex, co-morbidities, previous history

Table 4. Catheterisation in different age

\begin{tabular}{|c|c|c|c|}
\hline \multirow[t]{2}{*}{$\begin{array}{l}\text { Age group } \\
\text { (Yrs) }\end{array}$} & \multicolumn{2}{|c|}{$\begin{array}{l}\text { Need for } \\
\text { catheterization }\end{array}$} & \multirow[t]{2}{*}{ p } \\
\hline & Yes & No & \\
\hline$<20$ & 0 & 17 & \\
\hline $21-40$ & 7 & 102 & 0.1 \\
\hline $41-60$ & 11 & 36 & \\
\hline 60 & 5 & 22 & \\
\hline
\end{tabular}


Table 5. Onset of spinal headache

\begin{tabular}{|l|r|r|r|}
\hline $\begin{array}{l}\text { Age group } \\
\text { (Yrs) }\end{array}$ & Onset of spinal headache & \multicolumn{1}{|c|}{ p } \\
\hline & Yes & No & \\
\hline$<20$ & 4 & 13 & \\
\hline $21-40$ & 26 & 83 & $<0.05$ \\
\hline $41-60$ & 4 & 43 & \\
\hline 60 & 3 & 24 & \\
\hline
\end{tabular}

of headache and type of operation (table 1). As the table 2 suggests, there were 20 patients in control group and 17 in the case group who developed spinal headache, but this was not statistically significant $(p=0.4)$. It was noted that more patients in the control group, who were given 24 hours bed rest, needed catheterisation (Table 3). Among 100 patients in the group, 16 needed the procedure as opposed to only seven patients in the study group.

Since the onset of headache was not significant in control and study groups (Table 2), the total patients were analysed for the onset of headache and the need for catheterisation. Most patients needing catheterisation belonged to 41-60 age group (Table 4). The patients aged 21 to 40 years were most affected with the onset of spinal headache (Table 5). The older patients had less incidence of the same.

\section{DISCUSSION}

Post lumbar (post spinal or post dural) puncture headache is one of the common complications of therapeutic or diagnostic lumbar punctures. ${ }^{5} \mathrm{PLPH}$ is defined as any headache after a lumbar puncture that worsens within 15 minutes of sitting or standing and is relieved within 15 minutes of lying down (headache classification). ${ }^{3}$ Ninety percent of PLPH occurs within three days of the procedure and in $66 \%$ of the patients it starts in the first 48 hours. ${ }^{10}$
Table 6. Onset of headache after procedure above or below knee

\begin{tabular}{|l|r|r|r|}
\hline Type of operation & \multicolumn{1}{|c|}{ Onset of headache } & \multicolumn{1}{c|}{$p$} \\
\hline Knee and below & \multicolumn{1}{|c|}{ Yes } & \multicolumn{1}{c|}{ No } & \\
\hline Above knee & 24 & 117 & $<0.05$ \\
\hline
\end{tabular}

The pathophysiology of PLPH is still not fully described. It is well known that the puncture in the dura allows cerebrospinal fluid (CSF) to leak from the subarachnoid space, resulting in a decrease of CSF to leak from the subarachnoid space, resulting in a decrease of CSF volume and pressure. ${ }^{11}$ This CSF volume loss may cause a downward pull on pain-sensitive structures resulting in a headache. ${ }^{5}$ Alternatively, the loss of CSF may cause an increase in blood flow, resulting in arterial and venous vasodilatation and PLPH. A third PLPH explanation involves the role of $\mathrm{P}$ substance and the regulation of Neurokinin 1 receptors..$^{4,12}$

Many publications have focused on treatment once the symptoms present. The prevention of PLPH, however, is equally important- especially if we aim for early mobilisation of the orthopaedic patients post surgical procedures in lower limbs. Immobilisation is one of the methods described to prevent PLPH or recover from it. It was Sicard in 1902, who first recommended bed rest after a lumber puncture. He recommended rest for 24 hours after the procedure. Symptoms can be relieved by rest, but it is debatable whether bed rest prevents the development of symptoms. 4,5

Table 7. Patients needing catheterisation after procedure above or below knee

\begin{tabular}{|l|r|r|r|}
\hline \multicolumn{1}{|c}{$\begin{array}{c}\text { Type of } \\
\text { operation }\end{array}$} & \multicolumn{2}{c|}{$\begin{array}{c}\text { Need for } \\
\text { catheterization }\end{array}$} & \multicolumn{1}{c|}{ p } \\
\hline & Yes & No & \\
\hline Knee and below & 10 & 131 & $<0.05$ \\
\hline Above knee & 15 & 44 & \\
\hline
\end{tabular}


In our study we aimed to compare the effects of bed rest versus early mobilisation in patients after spinal anaesthesia, who had undergone lower limb orthopaedic procedures. It was a single centre, prospective, randomised study carried out in a leading teaching institute of our country. The demographics of the patients was evaluated according to age group, sex, co-morbidities, previous history of operative procedures and the current operation. These parameters were not significant between the control and the study groups.

The onset of spinal headache in the two groups did not show statistical significance (Table 2). This showed that the body position was not contributory to the onset of headache, since similar number of the patients in both groups experienced headache. Studies also have shown that early mobilisation after spinal anaesthesia does not increase the occurrence of headache.1,2,4,5 In our study total patients having headache was $37(18.5 \%)$. This is much less than the quoted figures of up to $70 \% .^{1-3}$

As it was seen that the onset of headache was not significant in the groups, the total patients were analysed for the onset of headache and the need for catheterisation. Onset of headache was seen mostly in the age group of 21 to 40 yrs old patients, which seems significant in the said age group (Table 5). We also find that the onset of headache is less in elderly patients. This correlates with the findings described by Jabbari in his review article. ${ }^{13}$

Further, patients who were given bed rest seemed to have difficulty in voiding urine in post-operative period. As is evident in table 3, the control group which was given bed rest needed more bladder catheterisation than the study group. Most of the patients needing catheterisation were in 4 to 60 years age group (Table 4). The patients who were allowed to sit or stand seemed to be more able to self-void in post-operative period, as also shown by Jong et al. ${ }^{14}$

We also noted that the onset of headache was in fewer patients who had procedures above the knee (Table 6). But the need for catheterisation was more in patients with similar procedures (Table 7). Both of these findings seem to be significant.

\section{CONCLUSIONS}

We conclude that early post operative mobilisation of the patient is not contributory to PLPH; also, ability to put patient in sitting position or allowing him/her to stand allows for easier bladder voiding as well as early initiation of rehabilitation measures. Since PLPA is not associated with position, we can ambulate the patient as early as the patient feels comfortable; this can give positive results in early mobilisation and rehabilitation and early discharge from the hospital.

To cite this article: Kayastha N, Joshi A, Kunwar B, Khadka S. Effect of body position on post-lumbar puncture headache and urinary retention after spinal anaesthesia in orthopaedic Cases: Concerns in postoperative ambulation and rehabilitation. MJSBH. 2018;17(2):32-7.

Conflict of Interest: None declared

\section{REFERENCES}

1. Handler CE, Smith FR, Perkin GD, Rose FC. Posture and lumbar puncture headache: a controlled trial in 50 patients. Journal of the Royal Society of Medicine. 1982;75:404-7. 
PMid:7045365

2. Sudlow C, Warlow C. Posture and fluids for preventing post-dural puncture headache. Cocharane Database Syst Rev. 2002;2:CD1790.

3. Headache Classification Subcommittee of the International Headache Society. The International Classific Handler CE, Smith FR, Perkin GD, Rose FC. Posture and lumbar puncture headache: a controlled trial in ation of Headache Disdorders: 2nd ed. Cephalgia. 2004;24(1):9-160.

4. Arevalo-Rodriguez I, Ciapponi A, Munoz L, Quintero RA, Bonfill Cosp X. Posture and fluids for preventing post-dural puncture headache (Protocol). The Cochrane Collaboration. 2011.

PMid:21342504

5. Davignon KR, Dennehy K. Update on postdural puncture headache. International Anaesthesiology Clinics. 2002;40(4):89-102.

DOI: https://doi.org/10.1097/00004311-200210000-00008

6. Kreutziger J, Frankenberger B, Luger TJ, Richard S, Zbinden. Urinary retention after spinal anaesthesia with hyperbaric prilocaine 2\% in an ambulatory setting. British Journal of Anaesthesia. 2010;104(5):582-6.

DOI: https://doi.org/10.1093/bja/aeq054

PMid:20338955

7. Baldini G, Bagry H, Aprikian A, Carli F. Postoperative Urinary Retention. Anaesthesiology. 2009; 110:1139-57.

DOI: https://doi.org/10.1097/ALN.0b013e31819f7aea PMid:19352147

8. Lingaraj K, Ruben M, Chan YH, Das De S. Identification of risk factors for urinary retention following total knee arthroplasty: a Singapore hospital experience. Singapore Med J. 2007;48(3):213.

PMid:17342289

9. Cresswell AB, Jassem W, Srinivasan P, Prachalias AA, Sizer E, Burnal W, et al. The effect of body position on compartmental intra-abdominal pressure following liver transplantation. Annals of Intensive Care. 2012;2(1): 512.

DOI: https://doi.org/10.1186/2110-5820-2-S1-S12

PMid:22873413 PMCid:PMC3390292

10. Turnbull DK, Shepherd DB. Post-dural puncture headache: pathogenesis, prevention and treatment. British Journal of Anaesthesia. 2003;91(5):718-29.

DOI: https://doi.org/10.1093/bja/aeg231

PMid:14570796

11. Grande PO. Mechanisms behind postspinal headache and brain stem compression following lumbar dural puncture- a physiological approach. Acta Anaesthesiologica Scandinavica. 2005;49(10):806-6.

DOI: https://doi.org/10.1111/j.1399-6576.2004.00601.x

12. Clark JW, Solomon GD, Senanayake PD, Gallagher C. Substance P concentration and history of headache in relation to postlumbar puncture headache: towards prevention. Journal of Neurology, Neurosurgery and Psychiatry. 1996;60(6):681-3.

DOI: https://doi.org/10.1136/jnnp.60.6.681

13. Jabbari A, Alijanpour E, Mir M, Hashem NB, Rabiea SM, Rupani MA. Post spinal puncture headache, an old problem and new concepts: review of articles about predisposing factors. Caspian J Intern Med.2013;4(1): 595-602.

PMid:24009943

14. Jong Y, Pinckaers JHFM, Brinki RM, Nijeholt AABL, Dekkers OM. Urinating Standing versus Sitting: Position Is of Influence in Men with Prostate Enlargement. A Systematic Review and Meta-Analysis. PLoS ONE. 2014 Jul;9(7):e101320.

DOI: https://doi.org/10.1371/journal.pone.0101320

PMid:25051345 PMCid:PMC4106761 